Y/ER-247

$\mathrm{Y}-12$

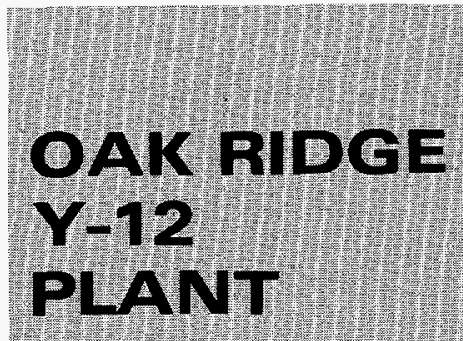

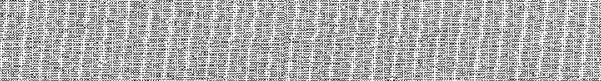

MARTUN MARUETRA

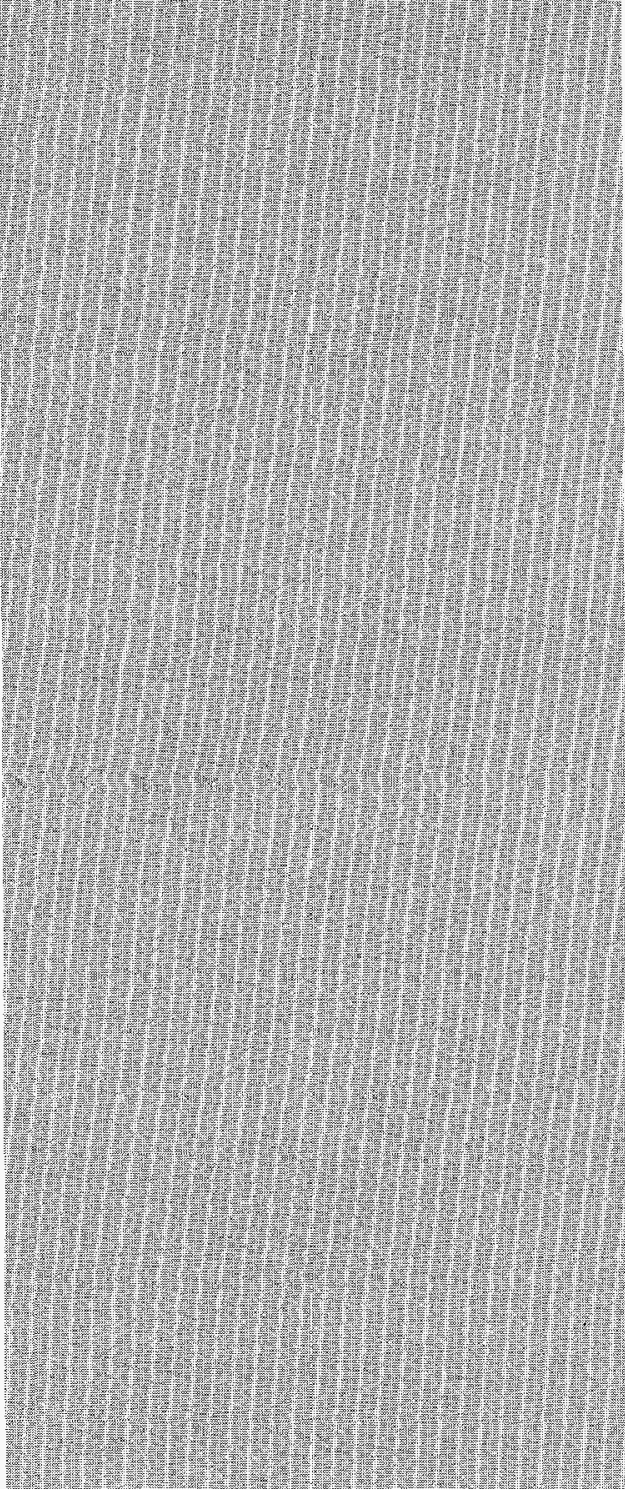

MNAGED BY

MARTIN MARIETTA ENERGY SYSTEMS, INC.

FOR THE UNITED STATES

DEPARTMEUT OF EIERGY

\section{Environmental Compliance Plan for the Y-12 Central Mercury Treatment System Project}

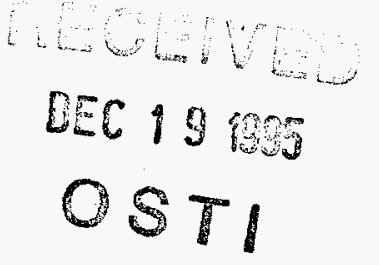

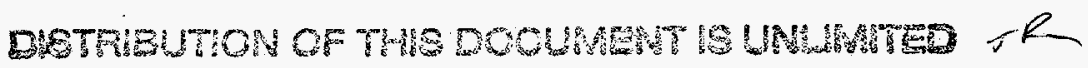




\section{DISCLAIMER}

This report was prepared as an account of work sponsored by an agency of the United States Government. Neither the United States Government nor any agency thereof, nor any of their employees, makes any warranty, express or implied, or assumes any legal liability or responsibility for the accuracy, completeness, or usefulness of any information, apparatus, product, or process disclosed, or represents that its use would not infringe privately owned rights. Reference herein to any specific commercial product, process, or service by trade name, trademark, manufacturer, or otherwise, does not necessarily constitute or imply its endorsement, recommendation, or favoring by the United States Government or any agency thereof. The views and opinions of authors expressed herein do not necessarily state or reflect those of the United States Government or any agency thereof.

This report has been reproduced directly from the best available copy.

Available to DOE and DOE contractors from the Office of Scientific and Technical Information, P.O. Box 62, Oak Ridge, TN 37831; prices available from 423-576-8401 (fax 423-576-2865).

Available to the public from the National Technical Information Service, U.S. Department of Commerce, 5285 Port Royal Rd., Springfield, VA 22161. 


\section{DISCLAMMER}

Portions of this document may be illegible in electronic image products. Images are produced from the best available original document. 
ENVIRONMENTAL COMPLIANCE PLAN FOR THE

Y-12 CENTRAL MERCURY TREATMENT SYSTEM PROJECT

September 1995

Prepared by:

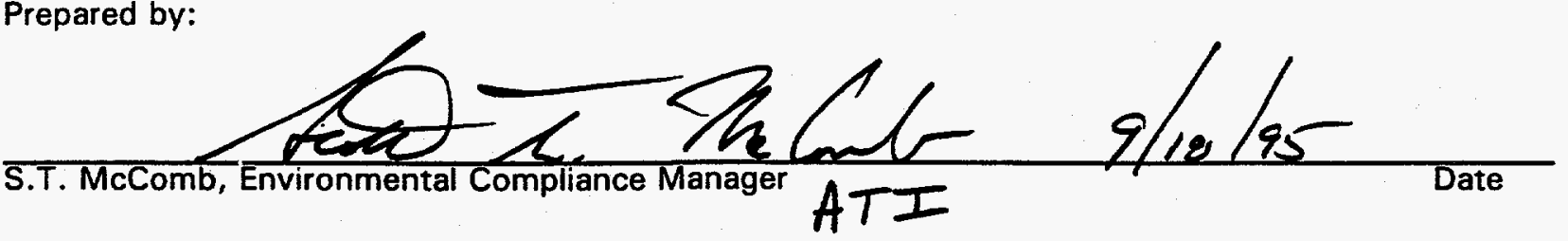

Concurred with:

Ac. Williams 9/18/95

A.C. Williamson, Technical Manager

Date

Concurred with:

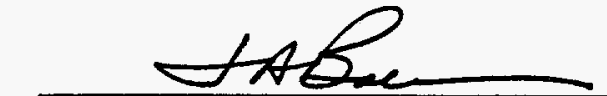

J.A. Baker, Design Manager
$9 / 19 / 95$

Date

Concurred with:

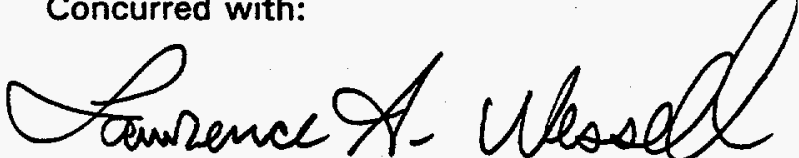

L.A. Weasel, Construction Manager

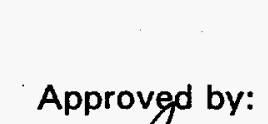

Approved by:

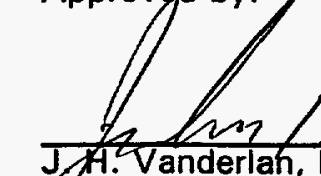

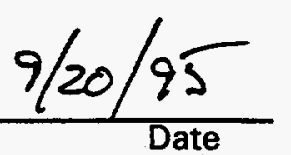

Date

J. Vanderlah, Project Manager

$\frac{9 / 20 / 95}{\text { pate }}$ 
Energy Systems Environmental Restoration Program

\title{
Environmental Compliance Plan for the Y-12 Central Mercury \\ Treatment System \\ Project
}

September 1995

\author{
Prepared for the \\ U.S. Department of Energy \\ Office of Environmental Management \\ under budget and reporting code EW 20 \\ Environmental Management Activities at the \\ OAK RIDGE Y-12 PLANT \\ Oak Ridge, Tennessee 37831-8169 \\ managed by \\ LOCKHEED MARTIN ENERGY SYSTEMS, INC. \\ for the \\ U.S. DEPARTMENT OF ENERGY \\ under contract DE-AC05-84OR21400
}




\section{PREFACE}

This Environmental Compliance Plan is specific to the construction phase of the installation of the Central Mercury Treatment System (CMTS) at the Oak Ridge Y-12 Plant. This document was prepared under Work Breakdown Structure 1.4.12.1.1.03.44 (Activity Data Sheet ER 2303, "Central Mercury Treatment System"). It was prepared to support the Lockheed Martin Energy Systems, Inc. (Energy Systems), Reduction of Mercury in Plant Effluent (RMPE) program. The purpose of this project Environmental Compliance Plan is to elaborate upon the compliance requirements outlined by the project plan; define the roles, responsibilities, and relationships needed to effectively implement requirements; define environmental compliance oversight activities; and establish environmental compliance record keeping and reporting requirements. 


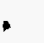




\section{CONTENTS}

EXECUTIVE SUMMARY $\ldots \ldots \ldots \ldots \ldots \ldots \ldots \ldots \ldots \ldots \ldots \ldots$ vii

ACRONYMS $\ldots \ldots \ldots \ldots \ldots \ldots \ldots \ldots \ldots \ldots \ldots \ldots \ldots \ldots \ldots \ldots$

1. INTRODUCTION $\ldots \ldots \ldots \ldots \ldots \ldots \ldots \ldots \ldots \ldots \ldots \ldots \ldots \ldots \ldots$

1.1 ENVIRONMENTAL COMPLIANCE PLAN OBJECTIVE $\ldots \ldots \ldots \ldots \ldots \ldots 1$

1.2 TECHNICAL OBJECTIVE $\ldots \ldots \ldots \ldots \ldots \ldots \ldots \ldots \ldots \ldots \ldots \ldots \ldots \ldots \ldots \ldots$

2. REQUIREMENTS $\ldots \ldots \ldots \ldots \ldots \ldots \ldots \ldots \ldots \ldots \ldots \ldots \ldots \ldots \ldots$

2.1 REGULATORY REQUIREMENTS $\ldots \ldots \ldots \ldots \ldots \ldots \ldots \ldots \ldots \ldots \ldots \ldots \ldots \ldots \ldots \ldots$

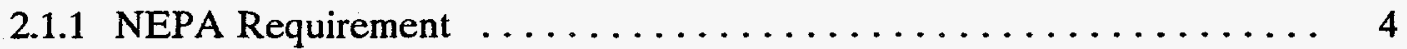

2.1.2 Air Monitoring Requirements $\ldots \ldots \ldots \ldots \ldots \ldots \ldots \ldots \ldots$

2.1.3 NPDES Monitoring Requirements ................. 5

2.1.4 Central Mercury Treatment System Regulatory Reguirements ...... . 5

2.1.5 Waste Disposal Requirements .................. 5

3. ORGANIZATIONAL ROLES AND RESPONSIBILITIES $\ldots \ldots \ldots \ldots \ldots \ldots$

3.1 ENERGY SYSTEMS ENVIRONMENTAL MANAGEMENT DIVISION . . 5

3.2 ENERGY SYSTEMS WASTE MANAGEMENT DIVISION $\ldots \ldots \ldots \ldots .6$

3.3 MK-FERGUSON, CONSTRUCTION MANAGER ............ 6

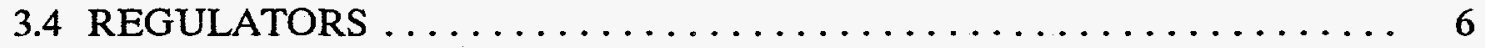

4. REPORTING AND RECORDS MANAGEMENT $\ldots \ldots \ldots \ldots \ldots \ldots$

4.1 HAZARDOUS CHEMICAL INVENTORY $\ldots \ldots \ldots \ldots \ldots \ldots \ldots \ldots$

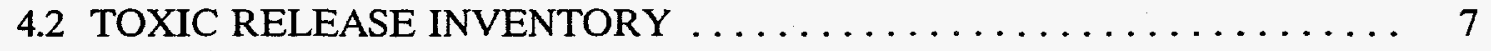

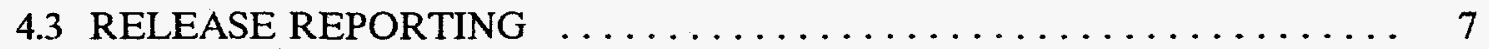




\section{EXECUTTIVE SUMMARY}

The objective of the Central Mercury Treatment System (CMTS) project is to install a system in Building 9623 to treat mercury-contaminated groundwater from sumps located in the basements of Buildings 9201-4, 9201-5, and 9204-4 so that discharges from the new outfall (Outfall 551) are within the National Pollutant Discharge Elimination System limits for mercury $(\mathrm{Hg})$ and $\mathrm{pH}$. This Environmental Compliance Plan elaborates upon the compliance requirements outlined by the project plan by defining roles, responsibilities, and relationships needed to effectively implement requirements; defining environmental oversight activities; and establishing environmental compliance record keeping and reporting requirements. This plan presents the environmental management regulatory requirements and the project's plan for compliance.

This project will be performed pursuant to a National Environmental Policy Act Categorical Exclusion (CX-Y12-338). An air permit exemption letter has been prepared (Y/TS-1394) to document the rationale for not requiring a Tennessee Air Pollution Control Board Permit. 
.

,

1

- 


\section{ACRONYMS}

CMTS
CX
D\&D
DOE
EMD
Energy Systems
FPSC
ID
LDR
MK-F
MSDS
NEPA
NPDES
PCB
RCRA
RMPE
SPCC
TDEC

Central Mercury Treatment System

categorical exclusion

decontamination and demolition

U.S. Department of Energy

Environmental Management Division

Lockheed Martin Energy Systems, Inc.

fixed price subcontractor

identification

land disposal restriction

MK-Ferguson

Material Safety Data Sheet

National Environmental Policy Act

National Pollutant Discharge Elimination System

polychlorinated biphenyl

Resource Conservation and Recovery Act

Reduction of Mercury in Plant Effluent

Spill Prevention Control and Countermeasures

Tennessee Department of Environment and Conservation 


\section{INTRODUCTION}

\subsection{ENVIRONMENTAL COMPLIANCE PLAN OBJECTIVE}

The purpose of this Environmental Compliance Plan is to elaborate upon the compliance requirements outlined by the project plan; define roles, responsibilities, and relationships needed to effectively implement requirements; define environmental compliance oversight activities; and establish environmental compliance record keeping and reporting requirements.

This project Environmental Compliance Plan promotes compliance with all applicable Y-12 Plant, state, and federal requirements and shall not be modified without written concurrence of the project team and written approval of the project manager. Major changes in the scope of work or site conditions will result in an addendum to this project Environmental Compliance Plan. The addendum will be approved by the project manager and submitted to the U.S. Department of Energy (DOE) for information.

\subsection{TECHNICAL OBJECTIVE}

The technical objective is to install a system in Building 9623 to treat mercurycontaminated groundwater from sumps located in the basements of Buildings 9201-4, 9201-5, and 9204-4 so that discharges from the new outfall (Outfall 551) are within the National Pollutant Discharge Elimination System (NPDES) limits for mercury $(\mathrm{Hg})$ and $\mathrm{pH}$.

Studies conducted by the Reduction of Mercury in Plant Effluent (RMPE) team have resulted in the selection of filtration and carbon absorption as the most economical method for removing mercury from the groundwater collected in Building 9201-4, 9201-5, and 9204-4 sumps. This method will be used to meet the proposed limits of 2 parts per billion (ppb) mercury for the monthly average, $4 \mathrm{ppb}$ mercury for the daily maximum, and a $\mathrm{pH}$ between 6 and 9 .

\section{REQUIREMENTS}

\subsection{REGULATORY REQUIREMENTS}

The team has identified, ensured the adequacy of, and will comply with the requirements of applicable laws and regulations and applicable requirements of DOE orders. Table 2.1 shows the environmental management regulatory requirements and the project's plans for compliance. 
Table 2.1. Environmental management regulatory requirements

\begin{tabular}{|c|c|c|c|}
\hline & Activity/Material & Requirements & $\begin{array}{c}\text { Project } \\
\text { compliance/assumption }\end{array}$ \\
\hline$\bullet$ & $\begin{array}{l}\text { Construction/demolition } \\
\text { wastes, other than } \\
\text { special wastes, resulting } \\
\text { from construction, } \\
\text { remodeling, repair, and } \\
\text { demolition of structures } \\
\text { and from road building }\end{array}$ & $\begin{array}{l}\text { TDEC } 1200-1-7-02(1)(b)(2)(x i i i) \\
\text { The use of solely natural rock and } \\
\text { dirt, pavement, and/or concrete or } \\
\text { brick rubble as fill material is not } \\
\text { required to have a permit. }\end{array}$ & $\begin{array}{l}\text { MK-Ferguson (MK-F) } \\
\text { will be responsible for } \\
\text { installing clean fill } \\
\text { material. }\end{array}$ \\
\hline & $\begin{array}{l}\text { Solid waste: garbage, } \\
\text { refuse, and other non- } \\
\text { RCRA (Resource } \\
\text { Conservation and } \\
\text { Recovery Act) } \\
\text { hazardous discarded } \\
\text { solid materials }\end{array}$ & $\begin{array}{l}40 \text { CFR and TCA 68-31-104. } \\
\text { Establishes solid waste } \\
\text { management and disposal } \\
\text { requirements. }\end{array}$ & $\begin{array}{l}\text { FPSC and MK-F will be } \\
\text { responsible for collection, } \\
\text { storage, and proper } \\
\text { disposal of solid waste } \\
\text { generated per the Waste } \\
\text { Management Plan. }\end{array}$ \\
\hline & $\begin{array}{l}\text { RCRA hazardous } \\
\text { wastes } \\
\text { - Hazardous waste } \\
\text { storage }\end{array}$ & $\begin{array}{l}40 \text { CFR 262.34, TDEC } \\
1200-1-11-03(4)(\mathrm{e}) . \mathrm{RCRA} \\
\text { hazardous waste must be } \\
\text { accumulated and stored in } \\
\text { accordance with requirements. }\end{array}$ & $\begin{array}{l}\text { Energy Systems will be } \\
\text { responsible for collection, } \\
\text { storage, and proper } \\
\text { disposal of hazardous } \\
\text { waste. }\end{array}$ \\
\hline & $\begin{array}{l}\text { Hazardous waste } \\
\text { storage restricted from } \\
\text { land disposal (LDR) }\end{array}$ & $\begin{array}{l}40 \text { CFR } 268.50 \text {. Comply with } \\
\text { labeling and record keeping } \\
\text { requirements. }\end{array}$ & $\begin{array}{l}\text { Any LDR waste will be } \\
\text { properly labeled and } \\
\text { appropriate records kept } \\
\text { by Energy Systems. }\end{array}$ \\
\hline & $\begin{array}{l}\text { RCRA-listed or } \\
\text { characteristic hazardous } \\
\text { waste }\end{array}$ & $\begin{array}{l}40 \text { CFR 268, TDEC } 1200-1-11-.10 \text {. } \\
\text { All RCRA waste generated must } \\
\text { be treated to meet LDR treatment } \\
\text { standards before land disposal in a } \\
\text { Subtitle C permitted facility. } \\
\text { RCRA waste not restricted from } \\
\text { land disposal must be disposed of } \\
\text { in a Subtitle C facility. }\end{array}$ & $\begin{array}{l}\text { Any RCRA waste } \\
\text { generated will be } \\
\text { disposed of in a Subtitle } \\
\text { C facility by Energy } \\
\text { Systems Waste } \\
\text { Management } \\
\text { organization. }\end{array}$ \\
\hline & $\begin{array}{l}\text { Hazardous waste } \\
\text { transportation }\end{array}$ & $\begin{array}{l}40 \text { CFR 262, Subpart B; TDEC } \\
1200-1-11-.03(3) . \text { Hazardous waste } \\
\text { shipped off-site must be } \\
\text { manifested. } \\
49 \text { CFR } 171-180 .\end{array}$ & $\begin{array}{l}\text { Energy Systems will } \\
\text { manifest all RCRA } \\
\text { hazardous wastes } \\
\text { resulting from materials } \\
\text { the subcontractor brings } \\
\text { to the construction site. } \\
\text { Energy Systems will } \\
\text { ensure that any transport } \\
\text { of RCRA wastes off-site } \\
\text { has an EPA identification } \\
\text { number and is manifested } \\
\text { appropriately. }\end{array}$ \\
\hline
\end{tabular}


Table 2.1 (continued)

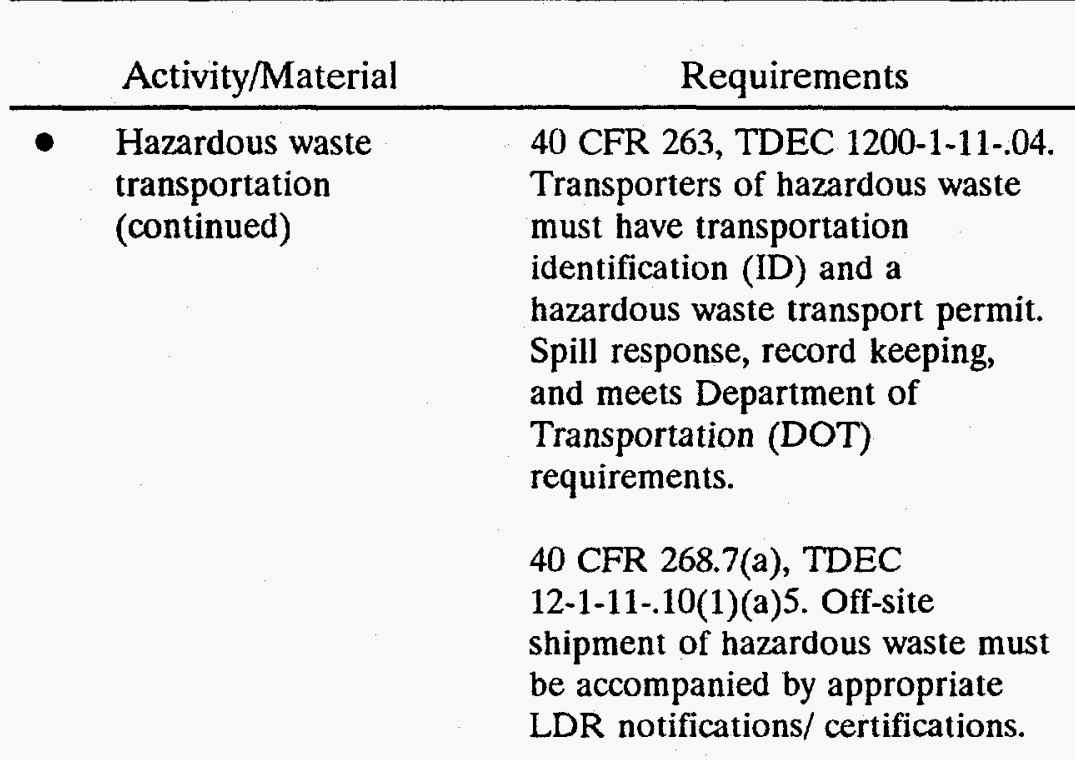

- Polychlorinated biphenyls (PCBs)

- Rad Waste

- Air Quality

- Fugitive emissions

- Permitting

- Air toxics

- Truck, equipment, tool cleaning and rinse water

\section{CFR 761.}

10 CFR 61, 10 CFR 71.

TDEC 1200-3-8-.01. Must take reasonable precaution to control fugitive dust. Fugitive dust must not be emitted as visible emissions beyond property boundary lines for more than $5 \mathrm{~min} / \mathrm{h}$ or $20 \mathrm{~min} / \mathrm{d}$.

TDEC 1200-3-9. Establishes permitting requirements for air pollution sources.

TDEC Policy (8-1-91) on emissions of air toxics.

40 CFR 122, TDEC 1200-4-10-.03. Discharges to waters of the state must be covered by an NPDES Permit. compliance/assumption

Energy Systems Waste Management will ensure that all hazardous waste shipped will have a transport ID, spill response, record keeping, and meets DOT requirements.

Energy Systems Waste Management will ensure that all hazardous waste shipped off-site will be accompanied by all appropriate LDR notification/certifications.

If any PCB-contaminated waste is encountered, project will require a Baseline Change Proposal.

Energy Systems Waste Management will manage the disposal of any radioactive waste generated by this project.

Dust suppression will be implemented by the FPSC and MK-F on an as-needed basis.

Existing Y-12 Fugitive Air Emissions Permit will cover construction activities.

Decontamination and demolition (D\&D) activities and FPSC construction activities are not expected to exceed acceptable ambient air concentrations.

Project will ensure that any wastewater discharged will be covered by the NPDES permit. 
Table 2.1 (continued)

\begin{tabular}{|c|c|c|}
\hline Activity/Material & Requirements & $\begin{array}{c}\text { Project } \\
\text { compliance/assumption }\end{array}$ \\
\hline - Sanitary wastewater & $\begin{array}{l}40 \text { CFR } 122 \text {, TDEC } 1200-4-10.03 \text {. } \\
\text { Discharges to waters of the state } \\
\text { must be covered by an NPDES } \\
\text { Permit. }\end{array}$ & $\begin{array}{l}\text { Sanitary wastewater will } \\
\text { be collected, treated, and } \\
\text { discharged per established } \\
\text { plant methods. }\end{array}$ \\
\hline $\begin{array}{l}\text { - Storage of oils or } \\
\text { other hazardous } \\
\text { substances }\end{array}$ & $\begin{array}{l}40 \text { CFR } 110 \text { and } 112 \text {. Establishes } \\
\text { spill prevention control and } \\
\text { countermeasures (SPCC) } \\
\text { requirements. }\end{array}$ & $\begin{array}{l}\text { FPSC and MK-F will } \\
\text { prepare and implement } \\
\text { an SPCC plan, if needed. }\end{array}$ \\
\hline $\begin{array}{l}\text { Hazardous chemical } \\
\text { inventory reporting } \\
\text { [includes all materials } \\
\text { requiring a Material } \\
\text { Safety Data Sheet } \\
\text { (MSDS)] }\end{array}$ & $\begin{array}{l}40 \text { CFR } 370 \text {. Facility owners or } \\
\text { operators to submit reports by } \\
\text { March } 1 \text { of each year. }\end{array}$ & $\begin{array}{l}\text { FPSC and MK-F to } \\
\text { submit inventory report } \\
\text { to Environmental } \\
\text { Management Dvision } \\
\text { (EMD) by January } 31 \text { to } \\
\text { allow preparation and } \\
\text { submission to regulatory } \\
\text { agencies by March } 1 .\end{array}$ \\
\hline $\begin{array}{l}\text { Toxic release inventory } \\
\text { reporting (includes all } \\
\text { toxic chemical waste } \\
\text { data for past calendar } \\
\text { year) }\end{array}$ & $\begin{array}{l}40 \text { CFR } 372 . \text { Facility owners or } \\
\text { operators to submit reports by } \\
\text { July } 1 \text { of each year. }\end{array}$ & $\begin{array}{l}\text { FPSC and MK-F to } \\
\text { submit inventory report } \\
\text { to EMD by January } 31 \text { to } \\
\text { allow preparation and } \\
\text { submission to regulatory } \\
\text { agencies by July } 1 \text {. }\end{array}$ \\
\hline - Release reporting & $\begin{array}{l}40 \text { CFR } 302 \text {. Establishes } \\
\text { hazardous substance release } \\
\text { reporting requirements. }\end{array}$ & $\begin{array}{l}\text { The FPSC or MK-F shall } \\
\text { immediately report any } \\
\text { releases of hazardous } \\
\text { substances or oils to the } \\
\text { Plant Shift } \\
\text { Superintendent and the } \\
\text { project team. }\end{array}$ \\
\hline NEPA & $\begin{array}{l}\text { National Environmental Policy } \\
\text { Act, } 40 \text { CFR } 1500-1508,10 \text { CFR } \\
1021,10 \text { CFR 1022. DOE } \\
\text { guidelines for compliance with } \\
\text { floodplain/wetland environmental } \\
\text { review requirements. Executive } \\
\text { Order } 11988 \text {, floodplain } \\
\text { management requirements. }\end{array}$ & $\begin{array}{l}\text { CMTS construction is } \\
\text { covered by categorical } \\
\text { exclusion (CX-Y12-338). }\end{array}$ \\
\hline
\end{tabular}

\subsubsection{NEPA Requirement}

The Central Mercury Treatment System (CMTS) project is being conducted pursuant to CX-Y12-338 “Categorical Exclusion (CS) for Maintenance Support Activities," approved December 1993, and "Programmatic Agreement Among the Department of Energy Oak Ridge Operations Office, the Tennessee State Historic Preservation Office, and the Advisory Council on Historic Preservation Concerning Management of Historical and Cultural Properties at the Oak Ridge Reservation," approved May 6, 1994. Proposed changes to the project were reviewed in November 1994 and deemed to not represent a significant change of scope, and the approved categorical exclusion (CX) was judged valid. Activities involved in constructing the CMTS will be governed primarily by environmental protection statutes addressing water quality and solid waste management. 


\subsubsection{Air Monitoring Requirements}

There will be no emission point sources requiring air permits. Construction activities such as grinding will require dust suppression to comply with fugitive air emission requirements. Fugitive dust emissions will be covered under the existing Y-12 Plant Fugitive Air Permits.

\subsubsection{NPDES Monitoring Requirements}

A Spill Prevention Control and Countermeasures (SPCC) Plan is now in place for the Y-12 Plant (Y/SUB/92-21704/1, August 1992). This plan can be supplemented, as necessary, to address any additional concerns related to the CMTS project. The fixed price subcontractor (FPSC) must develop and implement supplements to the SPCC Plan for any petroleum products or hazardous substances brought into the Y-12 Plant. An inventory record, including amounts, of all hazardous substances will be maintained by the subcontractor and submitted to the construction manager at the end of each calendar year and at project closeout. The subcontractor will report any release of petroleum products or hazardous substances immediately to the Plant Shift Superintendent, the construction manager, and the facility manager.

\subsubsection{Central Mercury Treatment System Regulatory Requirements}

Environmental requirements for the proposed Oak Ridge Y-12 CMTS project are outlined in Table 2.1. These requirements reflect a current understanding of the project and primarily address compliance with waste management, air pollution, and water pollution statutes.

\subsubsection{Waste Disposal Requirements}

A waste management plan has been prepared. No changes to the plan will be made without approval of the Configuration Control Board. The plan identifies all waste streams and their proper disposition.

\section{ORGANIZATIONAL ROLES AND RESPONSIBILITIES}

\subsection{ENERGY SYSTEMS ENVIRONMENTAL MANAGEMENT DIVISION}

Energy Systems Environmental Management Division via the environmental manager will maintain environmental oversight responsibility for the duration of the project. The environmental manager will be responsible for overseeing the environmental compliance of the project. The environmental manager's specific responsibilities include

- obtaining contractor signatures on environmental compliance documents as needed;

- developing and implementing environmental compliance plan and environmental oversight;

- coordinating with the DOE site office manager, DOE-ORO project manager, and environmental regulatory agencies to obtain approvals and concurrences;

- serving as the primary team contact for the environmental regulatory agencies; 
- coordinating preparation of all environmental compliance documentation;

- serving as the primary interface with other plants and programs on environmental compliance issues; and

- ensuring that the team is knowledgeable of regulatory response times and technical/procedural requirements.

\subsection{ENERGY SYSTEMS WASTE MANAGEMENT DIVISION}

Waste generated by the CMTS construction activities will be handled in accordance with the project Waste Management Plan.

\subsection{MK-FERGUSON, CONSTRUCTION MANAGER}

The construction manager for the project will be responsible for all construction activities, health and safety compliance during construction activities, and proper disposition of nonradioactive and nonhazardous waste and materials.

\subsection{REGULATORS}

The CMTS process will be located in Building 9623 at Y-12, a location subject to investigation and remediation pursuant to the Oak Ridge Reservation Federal Facility Agreement. Tennessee Department of Environment and Conservation (TDEC) has been advised of the decision to construct the CMTS. Any comments and suggestions offered will be considered and incorporated, as appropriate. The agency will be encouraged to visit and observe the project.

\section{REPORTING AND RECORDS MANAGEMENT}

Project reporting will include only those reports required to manage the project efficiently.

\subsection{HAZARDOUS CHEMICAL INVENTORY}

An inventory record, including amounts of all hazardous substances (includes all materials requiring an MSDS) will be maintained by the subcontractor and MK-F and submitted to the construction manager at the end of each calendar year and at project closeout. The EMD will incorporate the inventory record into the Y-12 Plant report for submission to regulatory agencies by March 1 of the following year. 


\subsection{TOXIC RELEASE INVENTORY}

An inventory record, including amounts, of all toxic chemical usage data will be maintained by the subcontractor and MK-F and submitted to the construction manager by May 10 of each calendar year and at project closeout. The EMD will incorporate the inventory record into the Y-12 Plant report for submission to regulatory agencies by July 1 of that calendar year.

\subsection{RELEASE REPORTING}

Any release of petroleum products or hazardous substances will be reported immediately to the construction manager or designee. 


\section{DISTRIBUTION}

1. L. V. Asplund

2. D. M. Matteo

3-4. P. T. Owen

5. D. C. White

6. J. A. Baker (Foster Wheeler), Bldg. 9734, MS-8130

7. W. H. Bessom, Bldg. 9723-16, MS-8146

8. K. M. Bracic, Bldg. 9734, MS-8130

9. CMTS Files, Bldg. 9734, MS-8130

10. T. C. Foster, Bldg. 9734, MS-8130

11. S. T. McComb, Bldg. 9983-58, MS-8247

12. T. W. Morris, Bldg. K-1225, MS-7294

13. G. M. Powers, Bldg. 9734, MS-8130

14. F. R. Trent, Bldg. 9736, MS-8122

15. J. H. Vanderlan, Bldg. 9734 , MS-8130

16. R. W. Weigel, Bldg. 9734, MS-8130

17. L. A. Wessell (MK-F), Bldg. 9983-81, MS-8178

18. A. C. Williamson, Bldg. 9734 , MS-8130

19. A. R. Winningham, Bldg. 9624 , MS-8222

20-21. A. K. Lee/DOE-OSTI, BIdg. 9731, MS-8175

22. Y-12 Central Files, Bldg. 9711-5, MS-8169

23. Central Research Library

24. ER Document Management Center-RC 